\title{
Penerapan Model Pembelajaran Kooperatif Tipe Student Team-Achievement Divisions (STAD) dengan Media Grafis untuk Meningkatkan Hasil Belajar IPS tentang Kegiatan Ekonomi pada Siswa Kelas V SD Negeri 1 Tamanwinangun Tahun Ajaran 2017/2018
}

\author{
Annas Hidayat Tulloh', Muhamad Chamdani' ${ }^{2}$ Ngatman $^{3}$ \\ 1,2,3 Universitas Sebelas Maret \\ annashidayat@student.uns.ac.id.
}

\section{Article History}

accepted 01/06/2019

approved 01/07/2019

published 01/08/2019

\begin{abstract}
The objective of this research is to improve learning outcomes through cooperative learning model type of Student Team Achievement Divisions (STAD) using graphic media to improve social science learning about economic activity in Indonesia for the fifth-grade students of SDN 1 Tamanwinangun. This research belongs to a collaborative Classroom Action Research (CAR). Subjects of the research were 20 students of the fifth-grade. Techniques of collection data were learning outcomes test, observation, interview, and documentation. Validity of data in this research was analyzed using triangulation of sources and triangulation of technique. Data were analyzed using quantitative and qualitative descriptive analysis consisting of data reduction, data display, and drawing conclusion. The result of the research shows that the use of cooperative learning model type of Student Team-Achievement Divisions (STAD) using graphic media can improve social science learning outcome about economic activities for the fifth-grade students of SD Negeri 1 Tamanwinangun in the academic year of 2017/2018.

Keywords: Student Team-Achievement Divisions (STAD), graphic media, learning outcome social science

Abstrak

Tujuan penelitian ini meningkatkan hasil belajar melalui model pembelajaran kooperatif tipe Student Team Achievement Divisions (STAD) dengan media grafis dalam pembelajaran IPS tentang kegiatan ekonomi di Indonesia pada siswa kelas V SDN 1 Tamanwinangun. Penelitian ini merupakan penelitian tindakan kelas kolaboratif, dengan subjek penelitian siswa kelas $\mathrm{V}$ yang berjumlah 20 siswa. Teknik pengumpulan data pada penelitian ini, yaitu teknik tes, observasi, wawancara, dan dokumentasi. Uji validitas data menggunakan triangulasi sumber dan triangulasi teknik. Analisis data melalui reduksi data, penyajian data, dan penarikan kesimpulan. Hasil penelitian menunjukkan penerapan model pembelajaran kooperatif tipe Student Team-Achievement Divisions (STAD) dengan media grafis dapat meningkatkan hasil belajar IPS tentang kegiatan ekonomi pada siswa kelas V SD Negeri 1 Tamanwinangun tahun ajaran 2017/2018.
\end{abstract}

Kata kunci: Student Team-Achievement Divisions (STAD), media grafis, hasil belajar IPS 


\section{PENDAHULUAN}

Pendidikan merupakan investasi jangka panjang yang mendapat perhatian khusus dalam sejarah peradaban manusia. Pendidikan dalam kehidupan manusia ialah kebutuhan pokok dan mendasar yang harus dipenuhi. IImu Pengetahuan Sosial (IPS) sebagai mata pelajaran yang diajarkan di sekolah dasar mempelajari bermacam-macam fakta, konsep dan peristiwa tentang keadaan sosial. mata pelajaran IPS bertujuan agar peserta didik memiliki kemampuan: (1) mengenal konsepkonsep yang berkaitan dengan kehidupan masyarakat dan lingkungannya, (2) memiliki kemampuan dasar untuk berfikir logis dan kritis, rasa ingin tahu, memecahkan masalah, dan keterampilan dalam kehidupan sosial, (3) memiliki komitmen dan kesadaran terhadap nilai-nilai sosial dan kemanusiaan, (4) memiliki kemampuan berkomunikasi, bekerjasama dan berkompetensi dalam masyarakat yang majemuk, di tingkat lokal, nasional, dan global (Permendiknas Nomor 24 Tahun 2006). Selanjutnya Ilmu Pengetahuan Sosial, yang sering disingkat dengan IPS, adalah ilmu pengetahuan yang mengkaji berbagai disiplin ilmu sosial dan humaniora serta kegiatan dasar manusia yang dikemas secara ilmiah dalam rangka memberi wawasan dan pemahaman yang mendalam kepada peserta didik, khususnya di tingkat dasar dan menengah. Susanto (2016: 137)

Berdasarkan analisis nilai ujian tengah semester SD Negeri 1 Tamanwinangun kelas V tahun ajaran 2017/2018, nilai tertinggi yang diperoleh siswa yaitu 93 sedangkan nilai terendahnya yaitu 44 dengan rata-rata nilai yakni 74,15 , dengan KKM 72. Dari 20 siswa kelas $\mathrm{V}$, terdapat 11 siswa yang mendapat nilai hasil belajar di atas KKM atau sebanyak $55 \%$, sedangkan siswa yang mendapat nilai hasil belajar di bawah KKM sebanyak 9 siswa atau 45\%. Dari hasil observasi pada tanggal 22 November 2017, masalah rendahnya hasil belajar di atas disebabkan karena, (1) pada proses pembelajaran IPS di kelas lebih banyak didominasi oleh guru (teacher centered), (2) guru masih belum optimal mengadakan variasi, model, strategi, metode, selain itu guru belum memaksimalkan media yang ada, (3) di dalam proses belajar mengajar siswa kurang aktif mengajukan pertanyaan atau gagasan pemikirannya.

Salah satu model yang dapat diterapkan untuk meningkatkan hasil belajar IPS yaitu model pembelajaran kooperatif tipe Student Team Achievement Divisions (STAD).

Model pembelajaran kooperatif tipe Student Team Achievement Division (STAD) ialah salah satu model pembelajaran kooperatif yang paling sederhana, dan sangat baik untuk permulaan dalam melatih guru yang baru menggunakan model kooperatif. Penggunaan model ini juga sangat efektif apabila dikombinasikan dengan media yang menunjang dalam pembelajaran, salah satunya dengan menerapkan media grafis. Media grafis memiliki berbagai kelebihan yang dapat digunakan untuk mengatasi batasan-batasan waktu dan ruang.

Berdasarkan uraian di atas, rumusan masalah pada penelitian ini yaitu apakah penerapan model pembelajaran kooperatif tipe Student Team-Achievement Divisions (STAD) dengan media grafis dapat meningkatkan hasil belajar IPS tentang kegiatan ekonomi pada siswa kelas V SDN 1 Tamanwinangun tahun ajaran 2017/2018? Tujuan penelitian ini yaitu untuk meningkatkan hasil belajar melalui model pembelajaran 
kooperatif tipe Student Team Achievement Divisions (STAD) dengan media grafis dalam pembelajaran IPS tentang kegiatan ekonomi di Indonesia pada siswa kelas $\mathrm{V}$ SDN 1 Tamanwinangun tahun ajaran 2017/2018.

\section{METODE}

Penelitian ini dilaksanakan di SD Negeri 1 Tamanwinangun pada tahun ajaran 2017/2018 yang berlangsung dari Bulan November 2017 sampai Mei 2018. Subjek penelitian ini adalah siswa kelas $\mathrm{V}$ yang berjumlah 20 siswa terdiri dari 12 siswa putra dan 8 siswa putri. Data yang digunakan pada penelitian ini adalah data kuantitatif dan kualitatif yang diperoleh dari guru kelas $\mathrm{V}$, siswa kelas $\mathrm{V}$, dan hasil dokumen. Adapun teknik pengumpulan data yang digunakan adalah tes, observasi, wawancara, dan dokumentasi. Teknik uji validitas data pada penelitian ini menggunakan teknik triangulasi, yaitu triangulasi sumber dan triangulasi teknik. Triangulasi sumber yang digunakan yaitu siswa, guru, dan dokumen. Adapun triangulasi teknik yang digunakan yaitu tes, observasi, wawancara, dan dokumentasi. Teknik analisis data yang digunakan dalam penelitian ini yaitu analisis kuantitatif dan kualitatif yang meliputi tiga langkah, yaitu reduksi data, penyajian data, dan penarikan kesimpulan. Indikator kinerja penelitian yang ditargetkan dalam penelitian ini yaitu $80 \%$ untuk ketuntasan hasil belajar IPS siswa dengan KKM penelitian yaitu 75. Adapun prosedur penelitian ini menggunakan metode penelitian tindakan kelas (PTK) kolaboratif.

Menurut Wiriaatmaja (2009: 11) penelitian tindakan kelas merupakan penelitian yang mengkombinasikan prosedur penelitian dengan tindakan substantif, suatu tindakan yang dilakukan dalam disiplin inkuiri, atau suatu usaha seseorang untuk memahami apa yang sedang terjadi, sambil terlibat dalam sebuah proses perbaikan dan perubahan. Arikunto (2013: 137) mengemukakan empat tahapan dalam penelitian tindakan kelas, yaitu: (1) perencanaan, (2) pelaksanaan, (3) pengamatan, dan (4) refleksi.

\section{HASIL DAN PEMBAHASAN}

Penerapan model pembelajaran kooperatif tipe Student Team Achievement Division (STAD) dengan media grafis dalam peningkatan hasil belajar IPS pada siswa kelas V SD Negeri 1 Tamanwinangun dalam penelitian ini dilakukan dalam tiga siklus, setiap siklus terdiri atas dua pertemuan. Jumlah siswa kelas $\mathrm{V}$ selama penelitian berjumlah 20 siswa. Penerapan model pembelajaran kooperatif tipe Student Team Achievement Division (STAD) dengan media grafis dilaksanakan dengan langkahlangkah: (1) menyampaikan pokok bahasan yang akan dituangkan dalam bentuk grafis, (2) memeragakan media grafis, (3) membentuk kelompok kecil, (4) memberi tes evaluasi/kuis, (5) merekapitulasi skor kemajuan, (6) memberi penghargaan tim.

Langkah model kooperatif tipe Student Team Achievement Division (STAD) dengan media grafis tersebut merupakan perpaduan dari langkah yang diterangkan oleh Slavin (2008: 179) yaitu: (1) presentasi kelas, (2) tim, (3) kuis, (4) skor kemajuan individual, (5) penghargaan tim. Selanjutnya menurut Huda (2015:163) langkahlangkah penerapan STAD yaitu: (1) menata ruang kelas, (2) merangking siswa, (3) menentukan jumlah kelompok, (4) membentuk kelompok-kelompok, (5) merancang team building untuk setiap kelompok, (6) mempresentasikan materi pembelajaran (7) membagikan lembar kerja siswa, (8) menugaskan siswa mengerjakan kuis secara 
mandiri, (9) menilai dan menskor kuis siswa, (10) memberi penghargaan pada kelompok, (11) mengevaluasi perilaku-perilaku (anggota) kelompok.

Menurut Ruminiati (2007: 2.23) langkah-langkah penerapan media grafis yaitu: (1) menganalisis pokok bahasan yang akan dituangkan dalam bentuk grafis; (2) menyiapkan bahan-bahan yang digunakan; (3) memeragakan media grafis tersebut sehingga dapat dilihat jelas oleh seluruh siswa; (4) guru menjelaskan materi pelajaran melalui media grafis yang telah disiapkan sekaligus menanamkan nilai moral dan norma yang menjadi tujuan pembelajaran. Selanjutnya menurut Daryanto (2013: 122) langkah-langkah penerapan media grafis yaitu: (1) pemilihan materi, (2) mempersiapkan ruang kelas, (3) mempersiapkan siswa, (4) mempersiapkan pertanyaan dan penugasan yang nengaktifkan siswa, (5) penggunaan saat pembelajaran berlangsung.

Hasil belajar IPS tentang kegiatan ekonomi mengalami peningkatan pada tiap siklusnya dengan perbandingan sebagai berikut.

Tabel 1. Perbandingan Hasil Belajar IPS Siswa pada Siklus I sampai III.

\begin{tabular}{llll}
\hline & Siklus & Siklus & Siklus \\
& $\mathbf{I}$ & II & III \\
\hline Rata-rata & 76,39 & 75,46 & 85,08 \\
\% Ketuntasan & $63,89 \%$ & $72,61 \%$ & $85,78 \%$ \\
\hline
\end{tabular}

Berdasarkan tabel 1., diketahui bahwa nilai rata-rata yang diperoleh siswa pada siklus I yaitu 76,39 dengan persentase ketuntasan 63,89\%. Pada siklus II nilai rata-rata siswa menjadi 75,46 dengan persentase ketuntasan $72,61 \%$. Selanjutnya pada siklus III nilai rata-rata siswa semakin meningkat menjadi 85,08 dengan persentase ketuntasan $85,78 \%$ sudah melebihi target indikator kinerja penelitian.

Oleh karena itu, dapat disimpulkan bahwa terjadi peningkatan hasil belajar IPS tentang kegiatan ekonomi. Data yang diperoleh peneliti menunjukkan bahwa hasil belajar mengalami peningkatan.

\section{SIMPULAN}

Berdasarkan hasil penelitian dan pembahasan, dapat disimpulkan bahwa penerapan model pembelajaran kooperatif tipe Student Team Achievement Division (STAD) dengan media grafis dapat meningkatkan hasil belajar IPS tentang kegiatan ekonomi pada siswa kelas V SD Negeri 1 Tamanwinangun tahun ajaran 2017/2018.

\section{DAFTAR PUSTAKA}

Arikunto, S (2013). Prosedur Penelitian, Suatu Pendekatan Praktik. Jakarta: PT Rineka Cipta.

Daryanto (2013). Media Pembelajaran. Yogyakarta: Gava Media.

Huda, M. (2015). Model-Model Pengajaran dan Pembelajaran. Yogyakarta: Pustaka Pelajar.

Permendiknas Nomor 24 Tahun 2006

Ruminiati (2007). Pengembangan Pendidikan Kewarganegaraan SD. Jakarta: Direktorat Jenderal Tinggi Departemen Pendidikan Nasional.

Slavin. (2008). Teori, Riset, dan Praktik. Jakarta: Indeks. 
Volume 7 Nomor 2 Tahun 2019

Susanto, A. (2016). Teori Belajar dan Pembelajaran di Sekolah Dasar. Jakarta: Kencana Prenada Media Group.

Wiriaatmaja, R. (2009). Metode Penelitian Tindakan Kelas untuk Meningkatkan Kinerja Guru dan Dosen. Bandung: Remaja Rosdakarya. 